Check for updates

Cite this: New J. Chem., 2019, 43,6314

Received 6th February 2019, Accepted 20th March 2019

DOI: 10.1039/c9nj00651f

rsc.li/njc

\section{Do An(III) and Ln(III) ions form heteroleptic complexes with diglycolamide and hydrophilic BT(B)P ligands in solvent extraction systems? A spectroscopic and DFT study $\dagger$}

\author{
Irena Herdzik-Koniecko, (D) a Christoph Wagner, ${ }^{\text {bc }}$ Michael Trumm, ${ }^{\mathrm{b}}$ Udo Müllich, ${ }^{\mathrm{b}}$ \\ Bernd Schimmelpfennig, ${ }^{b}$ Jerzy Narbutt, (DD ${ }^{a}$ Andreas Geist (D) ${ }^{* b}$ and \\ Petra J. Panak ${ }^{\mathrm{bc}}$
}

\begin{abstract}
Time-Resolved Laser Fluorescence Spectroscopy (TRLFS) was used to study the complexation of Cm(III) and $\mathrm{Eu}(\mathrm{III})$ in solvent extraction systems consisting of an organic phase containing TODGA (tetra- $n$-octyl diglycolamide) as an extracting agent and an aqueous phase containing hydrophilic complexing agents, tetrasodium salts of 2,6-bis(5,6-di(3-sulphophenyl)-1,2,4-triazin-3-yl)pyridine, $\mathrm{SO}_{3}$-Ph-BTP ${ }^{4-}$, or 6,6'bis(5,6-di(3-sulphophenyl)-1,2,4-triazin-3-yl)-2,2'-bipyridine, $\mathrm{SO}_{3}-\mathrm{Ph}-\mathrm{BTBP}^{4-}$. Only one complex, homoleptic $\left[\mathrm{Cm}(\mathrm{TODGA})_{3}\right]\left(\mathrm{NO}_{3}\right)_{3}$, was found in the organic phase. No heteroleptic complexes of $\mathrm{Cm}(\mathrm{III})$ with TODGA and $\mathrm{SO}_{3}-\mathrm{Ph}-\mathrm{BTP}^{4-}$ have been detected. In contrast, in dilute aqueous $\mathrm{HClO}_{4}$ solutions containing TEDGA (a hydrophilic homologue of TODGA) and $\mathrm{SO}_{3}-\mathrm{Ph}_{-} \mathrm{BTP}^{4-}$ ligands, seven different $\mathrm{Cm}(\mathrm{II})$ species were identified by their distinct emission spectra. Apart from the emission bands corresponding to the hydrated $\mathrm{Cm}^{3+}$ cation and to the complexes $\left[\mathrm{Cm}\left(\mathrm{SO}_{3}-\mathrm{Ph}-\mathrm{BTP}\right)\right]^{-}$and $\left[\mathrm{Cm}(\mathrm{TEDGA})_{n}\right]^{3+}(n=1-3)$, two further emission bands were ascribed to heteroleptic complexes [Cm(TEDGA)( $\left.\left.\mathrm{SO}_{3}-\mathrm{Ph}-\mathrm{BTP}\right)\right]^{-}$and $\left[\mathrm{Cm}(\mathrm{TEDGA})_{2}\left(\mathrm{SO}_{3}-\mathrm{Ph}-\mathrm{BTP}\right)\right]^{-}$. In a similar aqueous solution containing TEDGA and $\mathrm{SO}_{3}-\mathrm{Ph}-\mathrm{BTBP}^{4-}$, only one heteroleptic complex was identified, $\left[\mathrm{Cm}(\mathrm{TEDGA})\left(\mathrm{SO}_{3}-\mathrm{Ph}-\mathrm{BTBP}\right)\right]^{-}$. In addition, quantum chemical optimisation of the structures of the postulated heteroleptic complexes was performed.
\end{abstract}

\section{Introduction}

Long-term radiotoxicity and the heat load of irradiated nuclear fuels are mainly due to the presence of transuranium (TRU) elements, particularly plutonium and americium. Recycling the TRU elements from irradiated nuclear fuels would lead to a significant reduction of this hazard, and to improved utilization of natural resources since less uranium mining for the production of new nuclear fuels would be required, decreasing the environmental footprint of nuclear energy. ${ }^{1-3}$ Hence, strategies for the separation of the TRU elements from irradiated nuclear fuels and their fissioning ("burning") in nuclear reactors are considered in many countries. ${ }^{4-6}$ The separation of plutonium is implemented in the PUREX process (Plutonium Uranium Reduction Extraction). ${ }^{7}$

\footnotetext{
${ }^{a}$ Institute of Nuclear Chemistry and Technology (IChTJ), Dorodna 16, 03-195 Warsaw, Poland

${ }^{b}$ Karlsruhe Institute of Technology (KIT), Institute for Nuclear Waste Disposal (INE), P. O. Box 3640, 76021 Karlsruhe, Germany. E-mail: andreas.geist@kit.edu ${ }^{c}$ Ruprecht-Karls-Universität Heidelberg, Institut für Physikalische Chemie, Im Neuenheimer Feld 234, 69120 Heidelberg, Germany

$\dagger$ Electronic supplementary information (ESI) available. See DOI: 10.1039/ c9nj00651f
}

Furthermore, also neptunium can be separated under similar conditions in an advanced version of the PUREX process. ${ }^{8,9}$ However, selective separation of the trivalent actinides, An(III), americium and curium, from the resulting PUREX raffinate, leaving the chemically similar lanthanide fission products, Ln(III), is extremely challenging. ${ }^{10}$ Nonetheless, this separation is extremely important since some lanthanide isotopes having large cross sections for neutron capture would significantly reduce the efficiency of fissioning actinides. Hence, highly selective ligands are required as extractants to achieve this separation.

Alkylated N-donor ligands containing a 2,6-bis(5,6-dialkyl1,2,4-triazin-3-yl)pyridine (BTP), 6,6'-bis(5,6-dialkyl-1,2,4-triazin3-yl)-2,2'-bipyridine (BTBP) or 2,9-bis(5,6-dialkyl-1,2,4-triazin-3yl)-1,10-phenanthroline (BTPhen) core structure have excellent selectivity for the extraction of An(III) over Ln(III) from nitric acid (see ref. 11-13 and the references therein). By exchanging the alkyl groups for sulfonated phenyl moieties, novel water-soluble $\mathrm{N}$-donor ligands were synthesised (Scheme 1), easily dissociating into anions of -4 charge, even in acidic aqueous solutions. These complexing agents retain the BT(B)P selectivity for An(III)over-Ln(III) complexation in the aqueous phase, offering new 

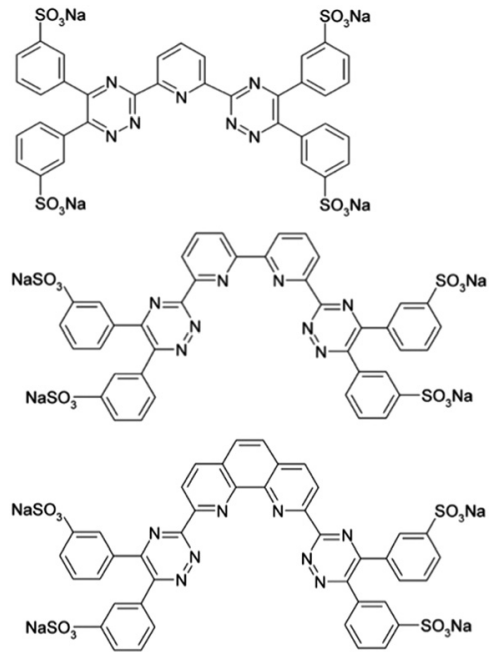

Scheme 1 Molecular structures of $\mathrm{SO}_{3}-\mathrm{Ph}-\mathrm{BTP}, \mathrm{SO}_{3}$-Ph-BTBP and $\mathrm{SO}_{3}-\mathrm{Ph}-\mathrm{BTPhen}$

possibilities for the development of separation processes. ${ }^{14-21}$ The combination of co-extraction of An(III) and Ln(III) from the PUREX raffinate by using a lipophilic diglycolamide ligand TODGA $\left(N, N, N^{\prime}, N^{\prime}\right.$-tetra- $n$-octyl-diglycolamide, Scheme 2$)$, followed by selective stripping of An(III) using a hydrophilic BTP, 2,6-bis(5,6di(3-sulphophenyl)-1,2,4-triazin-3-yl)pyridine, $\quad\left(\mathrm{SO}_{3}-\mathrm{Ph}-\mathrm{BTP}^{4-}\right.$, Scheme 1 top) dissolved in the aqueous phase, results in large separation factors of $\mathrm{An}(\mathrm{III})$ over $\mathrm{Ln}(\mathrm{III})$, which is the basis of various separation processes. ${ }^{22-26}$

However, the experimental results related to the complexation of An(III) with these anionic N-donor ligands in the aqueous phase were rather difficult to interpret. Since Am(III) and Cm(III) prefer 9-fold coordination, ${ }^{27,28}$ their coordination with three tridentate $\mathrm{SO}_{3}-\mathrm{Ph}-\mathrm{BTP}^{4-}$ ligands was expected. Indeed, the formation of the 1:3 M(III)-BTP complexes in solution both with hydrophobic $\mathrm{BTP}^{29-32}$ and with $\mathrm{SO}_{3}-\mathrm{Ph}-\mathrm{BTP}^{4-15,33}$ had been proven spectroscopically. In contrast, slope analysis of Am(III) distribution data (i.e. a log-log plot of Am(III) distribution ratio vs. $\mathrm{SO}_{3}-\mathrm{Ph}-\mathrm{BTP}^{4-}$ concentration) in the TODGA extraction system yielded a value close to $-2,{ }^{14}$ suggesting the formation of the $1: 2$ complex merely. A discrepancy between the results of the spectroscopic and solvent extraction studies was observed not only in the stoichiometries of the $\mathrm{M}$ (III)- $\mathrm{SO}_{3}$-Ph-BTP complexes but also in their stabilities. In a previous solvent extraction study on the complexation of $\mathrm{Am}(\mathrm{III})$ with $\mathrm{SO}_{3}-\mathrm{Ph}_{-} \mathrm{BTP}^{4-}$ only two complexes, $1: 1$ and $1: 2$, were found, ${ }^{34}$ with conditional stability constants lower by more than an order of magnitude than the corresponding values determined spectroscopically for the corresponding complexes of $\mathrm{Cm}(\mathrm{III}){ }^{15}$

Similar observations were made for the related tetradentate chelators $\mathrm{SO}_{3}$-Ph-BTBP and $\mathrm{SO}_{3}$-Ph-BTPhen (Scheme 1).

$$
\text { 等7 }
$$

Scheme 2 Molecular structure of TODGA.
The expected formation of $\mathrm{Cm}$ (III) $1: 2$ complexes with these ligands was confirmed by spectroscopic studies in aqueous solutions. ${ }^{17,21}$ However, slope analysis of liquid-liquid extraction experiments in the systems $\mathrm{SO}_{3}$-Ph-BTBP/TODGA and $\mathrm{SO}_{3}$-Ph-BTPhen/TODGA yielded values of approximately -1.3 and -0.8 , respectively, ${ }^{18,21}$ which implies the formation of only 1:1 complexes of An(III) with these tetra-N-dentate ligands.

These discrepancies show that the model of the extraction processes of An(III) ions, based on the presence of only their homoleptic complexes (with TODGA in the organic phase and with $\mathrm{SO}_{3}$-Ph-(BTP/BTBP/BTPhen) in the aqueous phase) may be incorrect. A hypothesis which explains these discrepancies suggests the formation of heteroleptic complexes of An(III) with TODGA and $\mathrm{SO}_{3}-\mathrm{Ph}-\mathrm{BTP}^{4-}$, e.g. $\left[\mathrm{Am}\left(\mathrm{SO}_{3}-\mathrm{Ph}-\mathrm{BTP}\right)(\mathrm{TODGA})_{2}\right]^{-}$, which could be extracted in the organic phase e.g. as ion pairs with the protonated extractant, TODGA $\cdot \mathrm{H}^{+}$. The formation of heteroleptic complexes to explain the behaviour of a similar solvent extraction system has been suggested earlier. ${ }^{35}$

This assumption requires careful investigation of the equilibria in each phase of solvent extraction systems containing two competing ligands - lipophilic and hydrophilic.

The aim of the present work was to find evidence for (or against) the existence of these hypothetical heteroleptic complexes, e.g. $\left[\mathrm{Cm}\left(\mathrm{SO}_{3}-\mathrm{Ph}-\mathrm{BTP}\right)(\mathrm{TODGA})_{2}\right]^{-}$, in the solvent extraction systems containing the competing lipophilic and hydrophilic ligands: TODGA and $\mathrm{SO}_{3}$-Ph-BTP (L), respectively. If such complexes really existed and their concentration in the organic phase increased with the concentration of the hydrophilic ligand, the slope of $\log D$ vs. $\log \left[\mathrm{L}^{4-}\right]$ in the extraction experiments would change from the expected value of -3 to -2 as observed experimentally. ${ }^{14}$ Evidence had been found for the existence of such heteroleptic complexes in similar solvent extraction systems containing two competing neutral chelating ligands, lipophilic DMDOHEMA and one of the hydrophilic DGA derivatives (TEDGA, Me-TEDGA or $\mathrm{Me}_{2}$-TEDGA, Scheme 3). TRLFS measurements confirmed the exclusive existence of $\left[\mathrm{Cm}(\mathrm{DGA})_{3}\right]^{3+}$ complexes in the aqueous phase. In the organic phase both the homoleptic [Cm(DMDOHEMA $\left.)_{n}\right]\left(\mathrm{NO}_{3}\right)_{3}$ and heteroleptic $\left[\mathrm{Cm}(\mathrm{DGA})_{x}(\mathrm{DMDOHEMA})_{y}\right]\left(\mathrm{NO}_{3}\right)_{3}$ complexes were detected. ${ }^{36}$

In the present work, time resolved laser fluorescence spectroscopy (TRLFS) studies were performed on (a) the complexation of $\mathrm{Cm}(\mathrm{III})$ in the solvent extraction system with TODGA and $\mathrm{SO}_{3}-\mathrm{Ph}$ $\mathrm{BTP}^{4-}$ and (b) the complexation of $\mathrm{Cm}$ (III) and $\mathrm{Eu}$ (III) in aqueous solutions with $N, N, N^{\prime}, N^{\prime}$-tetraethyl diglycolamide (TEDGA, Scheme 3) and $\mathrm{SO}_{3}-\mathrm{Ph}-\mathrm{BTP}^{4-}$ or $\mathrm{SO}_{3}-\mathrm{Ph}_{-\mathrm{BTBP}^{4-}}$.

The experimental results are supported by quantum chemical optimisation of the structures of postulated heteroleptic complexes.

$$
\begin{aligned}
& \left.\mathrm{H}_{3} \mathrm{C}_{2}^{-} \overbrace{0}^{\mathrm{C}_{2} \mathrm{H}_{5}}\right|_{0} ^{\mathrm{C}_{2} \mathrm{H}_{5}} \\
& \text { 等 }
\end{aligned}
$$

Scheme 3 Molecular structures of hydrophilic DGA derivatives, TEDGA, $\mathrm{Me}-\mathrm{TEDGA}$ and $\mathrm{Me}_{2}$-TEDGA. 


\section{Experimental}

\section{Chemicals}

For the TRLFS studies a $2.1 \times 10^{-5} \mathrm{~mol} \mathrm{~L}^{-1} \mathrm{Cm}\left(\mathrm{ClO}_{4}\right)_{3}$ solution with an isotopic mass distribution of $89.7 \% \mathrm{Cm}-248,9.4 \%$ Cm-246, $\leq 1 \%$ Cm-243, Cm-244, Cm-245 and Cm-247 was used. $\mathrm{SO}_{3}$-Ph-BTP, $\mathrm{SO}_{3}$-Ph-BTBP and TODGA were prepared according to literature procedures. ${ }^{14,37,38}$ TEDGA was supplied by Technocomm Ltd, Edinburgh, UK, and used as received.

\section{Preparation of TRLFS samples}

Stock solutions $\left(10^{-2} \mathrm{~mol} \mathrm{~L} \mathrm{~L}^{-1}\right)$ of $\mathrm{N}$-donor ligands were prepared by dissolving $9.49 \mathrm{mg}$ of $\mathrm{SO}_{3}$-Ph-BTP or $10.26 \mathrm{mg}$ of $\mathrm{SO}_{3}$-Ph-BTBP (tetrasodium salts) in $1 \mathrm{~mL}$ of $10^{-3} \mathrm{~mol} \mathrm{~L}^{-1} \mathrm{HClO}_{4}$. Using suitable dilutions of the stock solutions the $\mathrm{SO}_{3}-\mathrm{Ph}-\mathrm{BTP} /$ BTBP concentrations were adjusted to $5 \times 10^{-6} \mathrm{~mol} \mathrm{~L}^{-1}$ and $4 \times 10^{-7} \mathrm{~mol} \mathrm{~L}^{-1}$, respectively. A stock solution of $1 \mathrm{~mol} \mathrm{~L}^{-1}$ TEDGA was prepared by dissolving $244 \mathrm{mg}$ of TEDGA in $1 \mathrm{~mL}$ of $10^{-3} \mathrm{~mol} \mathrm{~L}^{-1} \mathrm{HClO}_{4}$, and the solutions used for titration experiments were prepared by subsequent dilutions.

Titration experiments were performed by adding $4.7 \mu \mathrm{L}$ of $\mathrm{Cm}$ (III) stock solution to $995 \mu \mathrm{L}$ of $10^{-3} \mathrm{~mol} \mathrm{~L}^{-1} \mathrm{HClO}_{4}$, resulting in an initial $\mathrm{Cm}(\mathrm{III})$ concentration of $10^{-7} \mathrm{~mol} \mathrm{~L}^{-1}$. After the addition of $\mathrm{SO}_{3}$-Ph-BTP or $\mathrm{SO}_{3}$-Ph-BTBP, the samples were shaken and equilibrated for 15 minutes before recording the emission spectrum. The TEDGA concentration was increased by stepwise addition of TEDGA solution. After each addition, an emission spectrum was recorded.

Solvent extraction experiments were performed by shaking each $0.5 \mathrm{~mL}$ organic $\left(0.2 \mathrm{~mol} \mathrm{~L}{ }^{-1}\right.$ TODGA +5 vol\% octanol in TPH ("hydrogenated tetrapropylene", a kerosene diluent)) and aqueous $\left(10^{-7} \mathrm{~mol} \mathrm{~L}^{-1} \mathrm{Cm}(\mathrm{III}), 20 \mathrm{mmol} \mathrm{L}{ }^{-1} \mathrm{SO}_{3}\right.$-Ph-BTP in $0.7 \mathrm{~mol} \mathrm{~L}^{-1} \mathrm{HNO}_{3}$ ) phases using a vortex shaker $(40 \mathrm{~Hz})$ for $15 \mathrm{~min}$, sufficient to attain equilibrium. The phases were separated by centrifugation and emission spectra were recorded.

\section{Determination of $\mathrm{SO}_{3}$-Ph-BTP in organic phases}

Transfer of $\mathrm{SO}_{3}$-Ph-BTP to the organic phase was determined spectrophotometrically by stripping $\mathrm{SO}_{3}$-Ph-BTP back to the aqueous phase and measuring the absorbance of the Fe(II)-SOPh-BTP complex on a Cary 6000i UV-vis spectrophotometer using cuvettes with a path length of $10 \mathrm{~mm}$.

Solutions containing $(1-20) \times 10^{-6} \mathrm{~mol} \mathrm{~L}^{-1} \mathrm{SO}_{3}$-Ph-BTP, $3 \times 10^{-4} \mathrm{~mol} \mathrm{~L}^{-1} \mathrm{Fe}\left(\mathrm{NO}_{3}\right)_{3}, 0.015 \mathrm{~mol} \mathrm{~L}^{-1} \mathrm{HNO}_{3}$ and $0.1 \mathrm{~mol} \mathrm{~L}^{-1}$ hydroxylammonium chloride in $1 \mathrm{~mol} \mathrm{~L}^{-1}$ acetate buffer $(\mathrm{pH}=4.5)$ were used to establish a calibration curve.

Since the formation of heteroleptic complexes requires the presence of metal ion complexes in the organic phase, transfer of $\mathrm{SO}_{3}$-Ph-BTP to the organic phase was determined (a) in the absence and (b) in the presence of Eu(III):

(a) Equal volumes of organic $\left(0.2 \mathrm{~mol} \mathrm{~L}^{-1}\right.$ TODGA +5 vol\% octanol in TPH) and aqueous $\left(20 \mathrm{mmol} \mathrm{L}{ }^{-1} \mathrm{SO}_{3}\right.$-Ph-BTP in $0.5 \mathrm{~mol} \mathrm{~L}^{-1} \mathrm{HNO}_{3}$ ) solutions were mixed using a vortex shaker $(40 \mathrm{~Hz})$ for $15 \mathrm{~min}$ and the phases were separated after centrifugation. An aliquot of the organic phase was shaken with water $(\mathrm{A} / \mathrm{O}=3)$ to strip $\mathrm{SO}_{3}-\mathrm{Ph}-\mathrm{BTP}^{4-}$. To this aqueous phase, solutions containing $\mathrm{Fe}\left(\mathrm{NO}_{3}\right)_{3}$, hydroxylammonium chloride and acetate buffer (at concentrations as used to establish the calibration curve) were added. The absorption spectrum was measured.

(b) Equal volumes of organic $\left(0.2 \mathrm{~mol} \mathrm{~L}^{-1}\right.$ TODGA +5 vol\% octanol in TPH) and aqueous $\left(20 \mathrm{mmol} \mathrm{L} \mathrm{L}^{-1} \mathrm{SO}_{3}\right.$-Ph-BTP + $30 \mathrm{mmol} \mathrm{L}{ }^{-1} \mathrm{Eu}\left(\mathrm{NO}_{3}\right)_{3}$ in $0.5 \mathrm{~mol} \mathrm{~L}^{-1} \mathrm{HNO}_{3}$ ) solutions were mixed using a vortex shaker $(40 \mathrm{~Hz})$ for $15 \mathrm{~min}$ and the phases were separated after centrifugation. An aliquot of the organic phase was shaken with water $(\mathrm{A} / \mathrm{O}=3)$ and with a solution of a $0.5 \mathrm{~mol} \mathrm{~L}^{-1}$ ammonium glycolate buffer, $\mathrm{pH}=4(\mathrm{~A} / \mathrm{O}=3)$ to strip $\mathrm{SO}_{3}-\mathrm{Ph}-\mathrm{BTP}^{4-}$. The second stripping step was necessary since Eu(III) was not completely stripped in the first step. These aqueous phases were further processed as described above.

\section{TRLFS setup}

The TRLFS (Time-Resolved Laser Fluorescence Spectroscopy) setup consisted of a Nd:YAG laser pumped (Continuum Surelite Laser) dye laser system (NARROWscan D-R Dye Laser) with a repetition rate of $10 \mathrm{~Hz}$. An ICCD camera with an integrated delay controller (iStar, Andor) was used to record the fluorescence signal after spectral decomposition using a Shamrock 303i spectrograph. For the excitation of $\mathrm{Cm}(\mathrm{III})$, a wavelength of $396.6 \mathrm{~nm}$ was applied. Scattering light and short-lived fluorescence of organic compounds were discriminated by a delay time of $1 \mu$ s between the excitation of $\mathrm{Cm}$ (III) and the measurement of the fluorescence signal. For the measurement of fluorescence lifetimes the delay time between excitation and recording of the fluorescence signal was increased stepwise in the range of $0-2100 \mu$ s.

\section{Quantum chemistry}

Quantum chemical optimisation of the structures of relevant heteroleptic complexes with TEDGA allows for a detailed view of their structural properties. Accordingly, we used the density functional theory (DFT) method to optimise the structures of $\left[\mathrm{Cm}\left(\mathrm{SO}_{3}-\mathrm{Ph}-\mathrm{BTP}\right)(\mathrm{TEDGA})_{n}\left(\mathrm{H}_{2} \mathrm{O}\right)_{6-3 n}\right]^{-}(n=0,1,2),\left[\mathrm{Cm}\left(\mathrm{SO}_{3}-\right.\right.$ Ph-BTBP $\left.)(\text { TEDGA })_{n}\left(\mathrm{H}_{2} \mathrm{O}\right)_{5-3 n}\right]^{-}(n=0,1)$ and 10-fold coordinated $\left[\mathrm{Cm}\left(\mathrm{SO}_{3}-\mathrm{Ph} \text {-BTBP }\right)(\mathrm{TEDGA})_{2}\right]^{-}$. In all calculations the BH-LYP functional $^{39}$ as implemented in the TURBOMOLE software package ${ }^{40}$ was used, following the protocol of a recent study. ${ }^{41}$ The Cm(III) ion is described by the effective core potential $\left(\mathrm{ECP} 0 \mathrm{MWB}^{42}\right)$ and corresponding basis sets of triple zeta quality. All other atoms are described by the standard def-TZVP basis set. ${ }^{43}$

\section{Results and discussion}

Part I: heteroleptic complexes in the organic phase by extraction experiments

The formation of heteroleptic complexes in the organic phase by extraction experiments would explain the aforementioned discrepancy between the results of slope analysis and spectroscopic studies. Spectroscopic techniques were applied to probe their presence in the systems studied. 

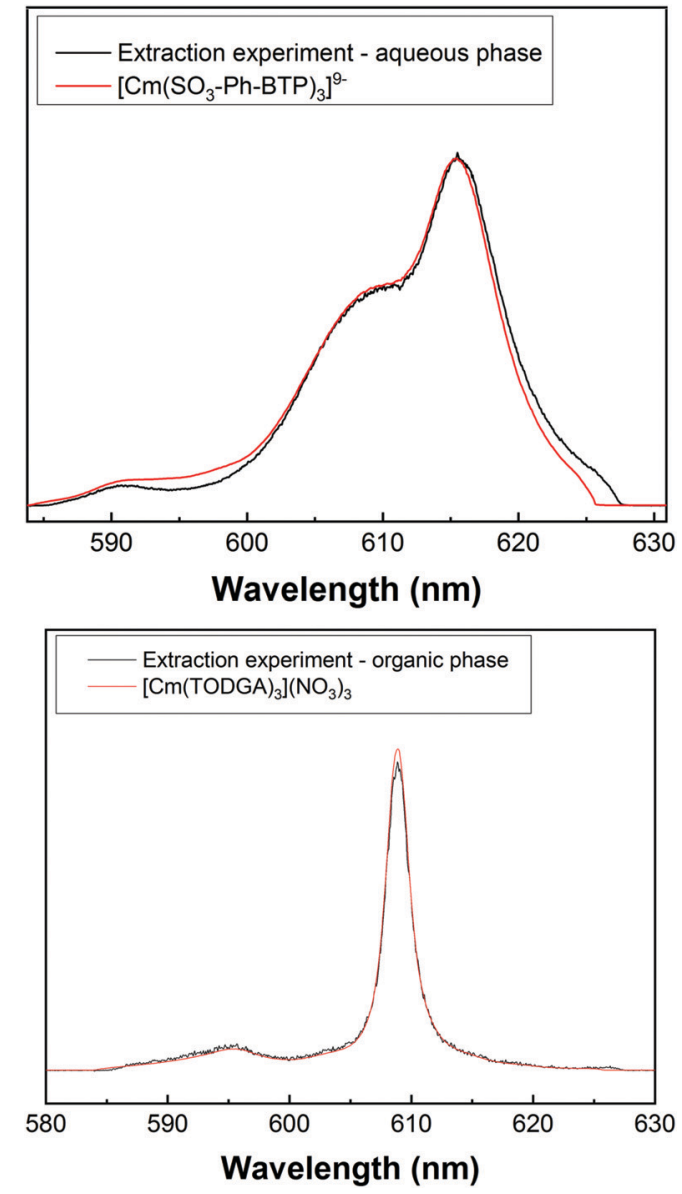

Fig. $1 \mathrm{Cm}(\mathrm{III})$ emission spectra of the aqueous phase (top) and the organic phase (bottom) from a solvent extraction experiment (aqueous phase, $10^{-7} \mathrm{~mol} \mathrm{~L}^{-1} \mathrm{Cm}(\mathrm{III}), 20 \mathrm{mmol} \mathrm{L}^{-1} \mathrm{SO}_{3}$-Ph-BTP in $0.7 \mathrm{~mol} \mathrm{~L}^{-1} \mathrm{HNO}_{3}$; organic phase, $0.2 \mathrm{~mol} \mathrm{~L}^{-1}$ TODGA +5 vol\% octanol in TPH) (black lines) compared to the spectra of homoleptic $\mathrm{Cm}(\mathrm{III})$ complexes, $\left[\mathrm{Cm}\left(\mathrm{SO}_{3}-\mathrm{Ph}-\mathrm{BTP}\right)_{3}\right]^{9-}$ in the aqueous phase and $\left[\mathrm{Cm}(\mathrm{TODGA})_{3}\right]\left(\mathrm{NO}_{3}\right)_{3}$ in the organic phase (red lines).

TRLFS investigations. $\mathrm{Cm}$ (III) $\left(10^{-7} \mathrm{~mol} \mathrm{~L}^{-1}\right.$ initially) was extracted from an aqueous phase $\left(20 \mathrm{mmol} \mathrm{L}^{-1} \mathrm{SO}_{3}\right.$-Ph-BTP in $\left.0.7 \mathrm{~mol} \mathrm{~L}^{-1} \mathrm{HNO}_{3}\right)$ to an organic phase $\left(0.2 \mathrm{~mol} \mathrm{~L}^{-1}\right.$ TODGA +5 vol\% octanol in TPH). Following phase separation, both phases were investigated by TRLFS and the emission spectra of Cm(III) were compared with those of known homoleptic Cm(III) complexes, $\left[\mathrm{Cm}\left(\mathrm{SO}_{3}-\mathrm{Ph}-\mathrm{BTP}\right)_{3}\right]^{9-}$ in the aqueous phase, ${ }^{15,33}$ and $\left[\mathrm{Cm}(\mathrm{TODGA})_{3}\right]\left(\mathrm{NO}_{3}\right)_{3}$ in the organic phase, ${ }^{44}$ Fig. 1 .

The exact agreement of the $\mathrm{Cm}$ (III) emission spectra of both the samples from the solvent extraction experiment containing $\mathrm{SO}_{3}-\mathrm{Ph}-\mathrm{BTP}$ and TODGA with those from the reference experiments indicates the exclusive formation of the $\left[\mathrm{Cm}\left(\mathrm{SO}_{3}-\mathrm{Ph}-\mathrm{BTP}\right)_{3}\right]^{9-}$ complex in the aqueous phase and the $\left[\mathrm{Cm}(\mathrm{TODGA})_{3}\right]\left(\mathrm{NO}_{3}\right)_{3}$ complex in the organic phase. Thus the amount of potentially formed heteroleptic complexes in the organic phase must be very low, if any.

To determine whether heteroleptic complexes were formed in the organic phase, even in small amounts, direct excitation measurements were applied using $\mathrm{Eu}(\mathrm{III})$ as a substitute. An extraction experiment was performed using an aqueous phase
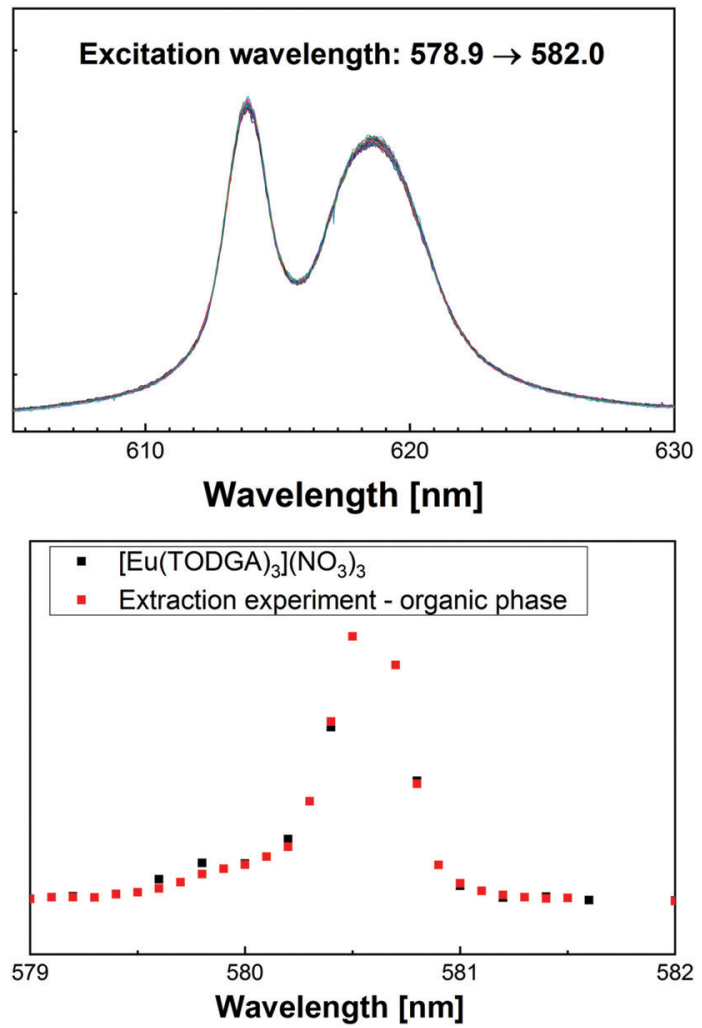

Fig. 2 Normalised emission spectra of the Eu(III) ${ }^{5} D_{0} \rightarrow{ }^{7} F_{2}$ transition at varied excitation wavelengths (top) and excitation spectrum of the Eu(III) ${ }^{5} D_{0} \rightarrow{ }^{7} F_{2}$ transition (bottom) in the organic phase from a solvent extraction experiment. Aqueous phase, $30 \mathrm{mmol} \mathrm{L}^{-1} \mathrm{Eu}(\mathrm{III})$ and $20 \mathrm{mmol} \mathrm{L}^{-1}$ $\mathrm{SO}_{3}-\mathrm{Ph}-\mathrm{BTP}$ in $0.5 \mathrm{~mol} \mathrm{~L}^{-1} \mathrm{HNO}_{3}$. Organic phase, $0.2 \mathrm{~mol} \mathrm{~L}{ }^{-1} \mathrm{TODGA}+$ 5 vol\% octanol in $\mathrm{TPH}$.

containing initially $30 \mathrm{mmol} \mathrm{L}{ }^{-1} \mathrm{Eu}(\mathrm{III})$ and $20 \mathrm{mmol} \mathrm{L}^{-1} \mathrm{SO}_{3^{-}}$ Ph-BTP in $0.5 \mathrm{~mol} \mathrm{~L}^{-1}$ nitric acid and an organic phase containing $0.2 \mathrm{~mol} \mathrm{~L}^{-1}$ TODGA $+5 \mathrm{vol} \%$ octanol in TPH. After shaking and phase separation, the emission spectra resulting from the ${ }^{5} \mathrm{D}_{0} \rightarrow{ }^{7} \mathrm{~F}_{2}$ transition of $\mathrm{Eu}(\mathrm{III})$ in the organic phase were measured as a function of the excitation wavelength. These emission spectra are shown in Fig. 2, as well as the excitation spectrum of the Eu(III) ${ }^{7} \mathrm{~F}_{0}$ band. The excitation spectrum of a sample containing exclusively $\left[\mathrm{Eu}(\mathrm{TODGA})_{3}\right]\left(\mathrm{NO}_{3}\right)_{3}$ is also shown for comparison.

The normalised emission spectra of the ${ }^{5} \mathrm{D}_{0} \rightarrow{ }^{7} \mathrm{~F}_{2}$ transition display the characteristic splitting of the $\left[\mathrm{Eu}(\mathrm{TODGA})_{3}\right]\left(\mathrm{NO}_{3}\right)_{3}$ complex $^{44}$ and do not change with altering the excitation wavelength (Fig. 2, top). Furthermore, the excitation spectrum of the ${ }^{5} \mathrm{D}_{0} \rightarrow{ }^{7} \mathrm{~F}_{2}$ transition shows only one emission band corresponding to the exclusive formation of $\left[\mathrm{Eu}(\mathrm{TODGA})_{3}\right]\left(\mathrm{NO}_{3}\right)_{3}$ in the organic phase (Fig. 2, bottom).

Quantification of $\mathrm{SO}_{3}-\mathrm{Ph}-\mathrm{BTP}$ transfer to the organic phase. $\mathrm{SO}_{3}-\mathrm{Ph}-\mathrm{BTP}$ transfer to the organic phase $\left(0.2 \mathrm{~mol} \mathrm{~L}^{-1}\right.$ TODGA + 5 vol\% 1-octanol in TPH) was studied by measuring the absorption of the complex formed with $\mathrm{Fe}(\mathrm{II})$ and $\mathrm{SO}_{3}-\mathrm{Ph}-\mathrm{BTP}$. Absorption spectra for (1-20) $\times 10^{-6} \mathrm{~mol} \mathrm{~L}^{-1} \mathrm{SO}_{3}$-Ph-BTP in $10 \mathrm{mmol} \mathrm{L}^{-1} \mathrm{HNO}_{3}$ were recorded. Fig. S1 (top) (ESI $\dagger$ ) shows the spectra for (1-4) $\times 10^{-6} \mathrm{~mol} \mathrm{~L}^{-1} \mathrm{SO}_{3}$-Ph-BTP. Calibration 
curves for the two wavelengths corresponding to the absorbance maxima are shown in Fig. S1 (bottom) (ESI $\dagger$ ).

In a preliminary experiment, an aqueous sample containing $20 \mathrm{mmol} \mathrm{L}^{-1} \mathrm{SO}_{3}$-Ph-BTP in $0.5 \mathrm{~mol} \mathrm{~L}{ }^{-1} \mathrm{HNO}_{3}$ was mixed with an organic phase consisting of $0.2 \mathrm{~mol} \mathrm{~L}^{-1}$ TODGA +5 vol\% 1-octanol in TPH $(\mathrm{A} / \mathrm{O}=1)$. The organic sample was shaken with water $(\mathrm{A} / \mathrm{O}=3)$ to strip $\mathrm{SO}_{3}-\mathrm{Ph}-\mathrm{BTP}^{4-}$. An absorption spectrum of this aqueous phase was recorded. No absorption signal of the $\mathrm{Fe}(\mathrm{II})-\mathrm{SO}_{3}$-Ph-BTP complex was detected, i.e. its concentration was below the detection limit of $10^{-6} \mathrm{~mol} \mathrm{~L}^{-1}$. With the A/O ratio of 3 used to strip the organic phase, the concentration of $\mathrm{SO}_{3}$-Ph-BTP transferred to the organic phase was below $3 \times 10^{-6} \mathrm{~mol} \mathrm{~L}^{-1}$.

A further experiment was performed, mixing an organic phase $\left(0.2 \mathrm{~mol} \mathrm{~L}{ }^{-1}\right.$ TODGA +5 vol\% 1-octanol in kerosene) with an aqueous phase containing $\mathrm{Eu}(\mathrm{III})\left(20 \mathrm{mmol} \mathrm{L}^{-1} \mathrm{SO}_{3}\right.$-Ph-BTP + $30 \mathrm{mmol} \mathrm{L}^{-1} \mathrm{Eu}\left(\mathrm{NO}_{3}\right)_{3}$ in $\left.0.5 \mathrm{~mol} \mathrm{~L}^{-1} \mathrm{HNO}_{3}\right), \mathrm{A} / \mathrm{O}=1$. The organic phase was shaken with water $(\mathrm{A} / \mathrm{O}=3)$ and then with $0.5 \mathrm{~mol} \mathrm{~L}^{-1}$ $\mathrm{NH}_{4}$-glycolate $(\mathrm{pH}=4 ; \mathrm{A} / \mathrm{O}=3)$. The $\mathrm{SO}_{3}$-Ph-BTP concentrations in the stripping solutions were determined, resulting in an organic phase $\mathrm{SO}_{3}$-Ph-BTP concentration of $5.5 \times 10^{-5} \mathrm{~mol} \mathrm{~L}^{-1}$.

Under these experimental conditions, Eu(III) was almost completely extracted to the organic phase. Assuming the formation of a heteroleptic Eu(III) complex with one $\mathrm{SO}_{3}$-Ph-BTP molecule, its concentration in the organic phase would also be $5.5 \times 10^{-5} \mathrm{~mol} \mathrm{~L}^{-1}$, i.e. $0.2 \%$ relative to the $\left[\mathrm{Eu}(\mathrm{TODGA})_{3}\right]\left(\mathrm{NO}_{3}\right)_{3}$ complex. Such a small fraction is expected to remain undetected in the emission spectra.

Solvent extraction experiments: summary. In summary, only homoleptic complexes were identified in the aqueous and organic phases from solvent extraction experiments ([Cm( $\left.\left(\mathrm{SO}_{3}-\mathrm{Ph}-\mathrm{BTP}\right)_{3}\right]^{9-}$ and $\left[\mathrm{Cm} / \mathrm{Eu}(\mathrm{TODGA})_{3}\right]\left(\mathrm{NO}_{3}\right)_{3}$, respectively). No heteroleptic complexes of $\mathrm{Cm}(\mathrm{III}) / \mathrm{Eu}(\mathrm{III})$ were found in any phase of the extraction system. The amount of potentially formed heteroleptic complexes in the organic phase in the extraction experiment may be too low to be detected using the methods applied. However, the finding that $\mathrm{SO}_{3}$-Ph-BTP measurably partitions to the organic phase when higher concentrations of $\mathrm{Eu}(\mathrm{III})$ are extracted indicates the formation of heteroleptic complexes in the system-Eu(III) (or any other metal ion) is not expected to partition to the organic phase as a homoleptic $\mathrm{SO}_{3}$-Ph-BTP complex.

\section{Part II: heteroleptic complexes in monophasic aqueous solutions}

Further research was aimed at clarifying whether heteroleptic complexes of $\mathrm{Cm}$ (III) with the hydrophilic ligands $\mathrm{SO}_{3}-\mathrm{Ph}-\mathrm{BTP}^{4-}$ or $\mathrm{SO}_{3}-\mathrm{Ph}-\mathrm{BTBP}^{4-}$ and TEDGA - a water-soluble homologue of TODGA - would form in aqueous solutions.

Investigation of heteroleptic $\mathrm{SO}_{3}$-Ph-BTP/TEDGA complexes by TRLFS. The formation of heteroleptic complexes was studied by monophasic titration of aqueous solutions of $\mathrm{Cm}$ (III) with TEDGA (the water-soluble analogue of TODGA) in the presence of $\mathrm{SO}_{3}$-Ph-BTP. The normalised $\mathrm{Cm}$ (III) emission spectra resulting from the ${ }^{6} \mathrm{D}_{7 / 2}^{\prime} \rightarrow{ }^{8} \mathrm{~S}_{7 / 2}^{\prime}$ transition are shown in Fig. 3.

Prior to the first addition of TEDGA, the emission spectrum displays two emission bands at $593.9 \mathrm{~nm}$ and $602.3 \mathrm{~nm}$.

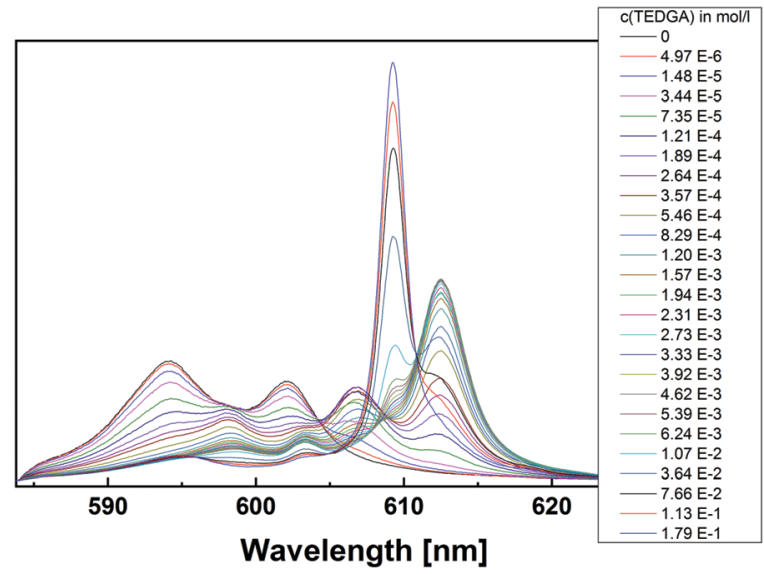

Fig. 3 Normalised emission spectra of $\mathrm{Cm}(\mathrm{III})$ in $10^{-3} \mathrm{~mol} \mathrm{~L}^{-1} \mathrm{HClO}_{4}$ solution at increasing TEDGA concentration in the presence of $5 \times 10^{-6} \mathrm{~mol} \mathrm{~L}^{-1}$ $\mathrm{SO}_{3}-\mathrm{Ph}-\mathrm{BTP}$.

These emission bands correspond to the aqua ion of $\mathrm{Cm}$ (III) and to the $\left[\mathrm{Cm}\left(\mathrm{SO}_{3}-\mathrm{Ph}-\mathrm{BTP}\right)\right]^{-}$complex, and are in excellent agreement with the literature. ${ }^{15}$

With increasing TEDGA concentration, five additional emission bands are observed at $598.3 \mathrm{~nm}, 603.3 \mathrm{~nm}$, $606.9 \mathrm{~nm}, 609.2 \mathrm{~nm}$ and $612.5 \mathrm{~nm}$. The emission bands at $598.3 \mathrm{~nm}$ and $603.3 \mathrm{~nm}$ are present in the range of TEDGA concentrations from $5 \times 10^{-6} \mathrm{~mol} \mathrm{~L}^{-1}$ to $3.6 \times 10^{-2} \mathrm{~mol} \mathrm{~L}^{-1}$, displaying only low intensities. These bands are attributed to the $[\mathrm{Cm}(\mathrm{TEDGA})]^{3+}$ and $\left[\mathrm{Cm}(\mathrm{TEDGA})_{2}\right]^{3+}$ complexes, ${ }^{36}$ and are in good agreement with the spectra observed for the chemically related lipophilic extractant TODGA. ${ }^{44}$ The emission band at $609.2 \mathrm{~nm}$ starts to form at TEDGA concentrations $\geq 2 \times$ $10^{-3} \mathrm{~mol} \mathrm{~L}^{-1}$ and is the dominating emission band at TEDGA concentrations $\geq 10^{-2} \mathrm{~mol} \mathrm{~L}^{-1}$. This emission band is attributed to the $\left[\mathrm{Cm}(\mathrm{TEDGA})_{3}\right]^{3+}$ complex in comparison with the literature. $^{36}$ This is in excellent agreement with the $\mathrm{Cm}$ (III) emission spectrum of the $\left[\mathrm{Cm}(\text { TODGA })_{3}\right]^{3+}$ complex. $^{44}$

Hence, the emission bands at $606.9 \mathrm{~nm}$ and $612.5 \mathrm{~nm}$ remain unidentified. The emission band at $606.9 \mathrm{~nm}$ is formed at TEDGA concentrations $\geq 5 \times 10^{-6} \mathrm{~mol} \mathrm{~L}^{-1}$. Formation of the second unidentified emission band at $612.5 \mathrm{~nm}$ begins at TEDGA concentrations $\geq 3.5 \times 10^{-5} \mathrm{~mol} \mathrm{~L}^{-1}$.

To investigate the composition of the complexes corresponding to the unidentified emission bands the pure component spectra of all species were obtained from the spectra of the titration experiment by peak deconvolution (Fig. 4). Applying the pure component spectra, the fractions of the present complex species were determined as a function of the TEDGA concentration.

Since the spectra of all the complex species containing solely $\mathrm{SO}_{3}$-Ph-BTP or TEDGA are known, the new emission bands at $606.9 \mathrm{~nm}$ and $612.5 \mathrm{~nm}$ may be attributed to the heteroleptic complexes containing $\mathrm{SO}_{3}-\mathrm{Ph}-\mathrm{BTP}^{4-}$ and TEDGA. Hence, the following equilibrium was assumed:

$$
\begin{gathered}
{\left[\mathrm{Cm}\left(\mathrm{SO}_{3}-\mathrm{Ph}-\mathrm{BTP}\right)(\mathrm{TEDGA})_{n-1}\right]^{-}+\text {TEDGA }} \\
\rightleftarrows\left[\mathrm{Cm}\left(\mathrm{SO}_{3}-\mathrm{Ph}-\mathrm{BTP}\right)(\mathrm{TEDGA})_{n}\right]^{-}
\end{gathered}
$$




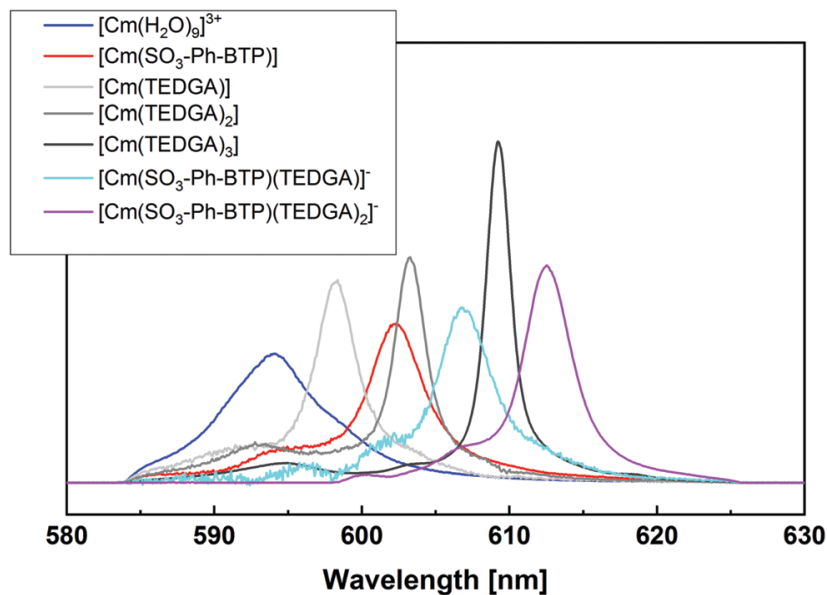

Fig. 4 Pure component spectra of the $\mathrm{Cm}(\mathrm{III})$ complexes with $\mathrm{SO}_{3}-\mathrm{Ph}$ $\mathrm{BTP}^{4-}$, and TEDGA and the heteroleptic complexes.

In the case of stepwise addition of TEDGA to the $\left[\mathrm{Cm}\left(\mathrm{SO}_{3}-\mathrm{Ph}\right.\right.$ BTP) $]^{-}$complex to form the subsequent heteroleptic complexes $\left[\mathrm{Cm}\left(\mathrm{SO}_{3}-\mathrm{Ph}-\mathrm{BTP}\right)(\mathrm{TEDGA})_{n}\right]^{-}(n=1,2)$, the log-log plot of the concentration ratio of $c\left[\mathrm{Cm}\left(\mathrm{SO}_{3}-\mathrm{Ph}-\mathrm{BTP}\right)(\mathrm{TEDGA})_{n}{ }^{-}\right]$to $c\left[\mathrm{Cm}\left(\mathrm{SO}_{3}{ }^{-}\right.\right.$ Ph-BTP)(TEDGA $\left.)_{n-1}^{-}\right] v s$. the free TEDGA concentration should yield a slope of one for each complexation step. Fig. 5 shows the plot, where slope analysis yields values of 1.0 and 1.1 for the subsequent complexation of the $\left[\mathrm{Cm}\left(\mathrm{SO}_{3}-\mathrm{Ph}-\mathrm{BTP}\right)\right]^{-}$complex with TEDGA, proving the formation of the expected heteroleptic complexes. Hence, the emission bands at $606.9 \mathrm{~nm}$ and $612.5 \mathrm{~nm}$ were assigned to the $\left[\mathrm{Cm}\left(\mathrm{SO}_{3}-\mathrm{Ph}-\mathrm{BTP}\right)(\mathrm{TEDGA})\right]^{-}$and $\left[\mathrm{Cm}\left(\mathrm{SO}_{3}-\mathrm{Ph}-\right.\right.$ BTP)(TEDGA $\left.)_{2}\right]^{-}$complexes, respectively.

The Cm(III) species distribution in aqueous solution titrated with TEDGA in the presence of $\mathrm{SO}_{3}$-Ph-BTP is shown in Fig. 6 . Under the experimental conditions $\left(10^{-3} \mathrm{~mol} \mathrm{~L}^{-1} \mathrm{HClO}_{4}, 5.0 \times\right.$ $10^{-6} \mathrm{~mol} \mathrm{~L}^{-1} \mathrm{SO}_{3}$-Ph-BTP), the first heteroleptic complex, $\left[\mathrm{Cm}\left(\mathrm{SO}_{3}-\mathrm{Ph}-\mathrm{BTP}\right)(\mathrm{TEDGA})\right]^{-}$has a maximum fraction of

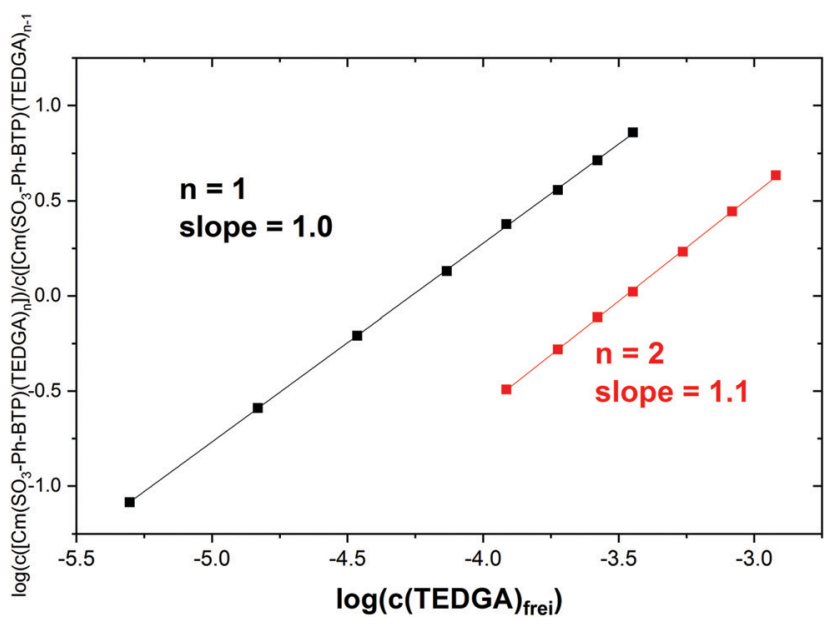

Fig. 5 Double logarithmic plot of the concentration ratio of $c\left[\mathrm{Cm}\left(\mathrm{SO}_{3}-\right.\right.$ $\left.\mathrm{Ph}-\mathrm{BTP})(\mathrm{TEDGA})_{n}{ }^{-}\right]$to $\mathrm{c}\left[\mathrm{Cm}\left(\mathrm{SO}_{3}-\mathrm{Ph}-\mathrm{BTP}\right)\left(\mathrm{TEDGA}_{n-1}{ }^{-}\right](n=1,2)\right.$ versus the free TEDGA concentration in the presence of $5 \times 10^{-6} \mathrm{~mol} \mathrm{~L}^{-1} \mathrm{SO}_{3}-$ Ph-BTP.

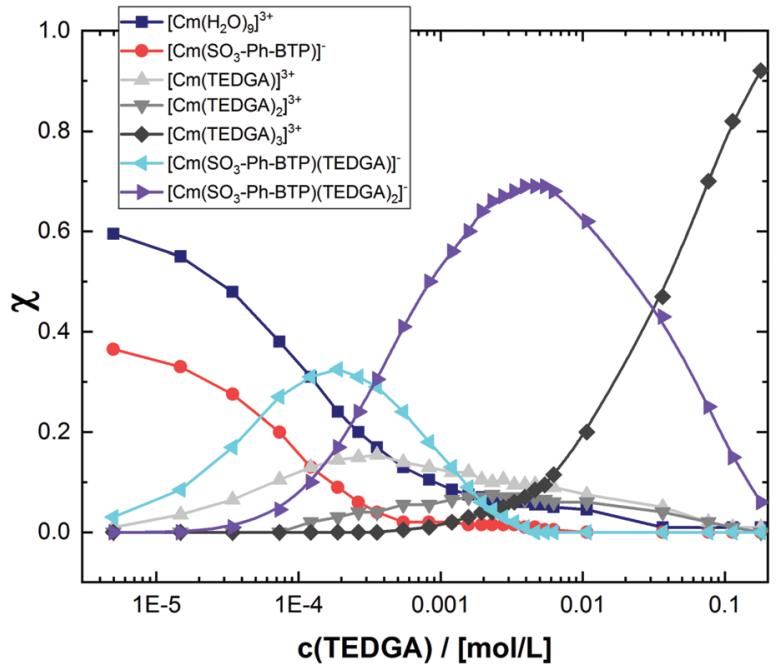

Fig. $6 \mathrm{Cm}$ (III) species distribution in $10^{-3} \mathrm{~mol} \mathrm{~L}^{-1} \mathrm{HClO}_{4}$ solution as a function of TEDGA concentration in the presence of $5 \times 10^{-6} \mathrm{~mol} \mathrm{~L}^{-1}$ $\mathrm{SO}_{3}-\mathrm{Ph}-\mathrm{BTP}$.

approximately $30 \%$ at $1.9 \times 10^{-4} \mathrm{~mol} \mathrm{~L} \mathrm{~L}^{-1}$ TEDGA. The second heteroleptic complex, $\left[\mathrm{Cm}\left(\mathrm{SO}_{3}-\mathrm{Ph}-\mathrm{BTP}\right)(\mathrm{TEDGA})_{2}\right]^{-}$is the dominating species for TEDGA concentrations between $3.5 \times 10^{-4} \mathrm{~mol} \mathrm{~L}^{-1}$ and $3.0 \times 10^{-2} \mathrm{~mol} \mathrm{~L}^{-1}$, with a maximum fraction of approximately $70 \%$ at a TEDGA concentration of $4.6 \times 10^{-3} \mathrm{~mol} \mathrm{~L}^{-1}$.

Fluorescence lifetimes of the heteroleptic $\mathrm{SO}_{3}-\mathrm{Ph}-\mathrm{BTP} /$ TEDGA complexes. To further characterise the heteroleptic complexes of $\mathrm{Cm}(\mathrm{III})$, the fluorescence lifetime of the $\left[\mathrm{Cm}\left(\mathrm{SO}_{3}-\mathrm{Ph}-\mathrm{BTP}\right)(\mathrm{TEDGA})_{2}\right]^{-}$complex was investigated by monitoring the fluorescence intensity at 612-613.5 nm. Fig. S2 (ESI $\dagger$ ) shows the natural logarithm of the observed fluorescence intensity as a function of delay time, and the slope was obtained from linear regression.

The fluorescence lifetime of the $\left[\mathrm{Cm}\left(\mathrm{SO}_{3}-\mathrm{Ph}-\mathrm{BTP}\right)(\mathrm{TEDGA})_{2}\right]^{-}$ complex is $333 \mu \mathrm{s}$. This is significantly longer than the fluorescence lifetime of $\left[\mathrm{Cm}\left(\mathrm{SO}_{3} \text {-Ph-BTP }\right)_{3}\right]^{9-}(\tau=202 \mu \mathrm{s})^{15}$ and shorter than the fluorescence lifetime of the $\left[\mathrm{Cm}(\mathrm{TODGA})_{3}\right]\left(\mathrm{NO}_{3}\right)_{3}$ complex $(\tau=517 \mu \mathrm{s}){ }^{44}$ The comparatively short fluorescence lifetime of $\left[\mathrm{Cm}\left(\mathrm{SO}_{3}-\mathrm{Ph}-\mathrm{BTP}\right)_{3}\right]^{9-}$ is induced by quenching effects of N-donor ligands in complexes with $\mathrm{Cm}(\mathrm{III}) .{ }^{45,46}$ Since diglycolamide ligands do not exhibit fluorescence quenching effects, ${ }^{44}$ quenching effects in a heteroleptic complex should be less pronounced than those in $\left[\mathrm{Cm}\left(\mathrm{SO}_{3}-\mathrm{Ph}-\mathrm{BTP}\right)_{3}\right]^{9-}$, but more than those in $\left[\mathrm{Cm}(\mathrm{TODGA})_{3}\right]\left(\mathrm{NO}_{3}\right)_{3}$. Thus, the observed fluorescence lifetime of $\left[\mathrm{Cm}\left(\mathrm{SO}_{3}-\mathrm{Ph}-\mathrm{BTP}\right)(\mathrm{TEDGA})_{2}\right]^{-}$is in agreement with inner-sphere coordination of TEDGA molecules, confirming the results obtained by slope analysis.

Investigation of heteroleptic $\mathrm{SO}_{3}$-Ph-BTBP/TEDGA complexes by TRLFS. Slope analysis of extraction experiments yields too low values for the $\mathrm{SO}_{3}$-Ph-BTBP/TODGA system as well. ${ }^{18}$ Thus, the formation of heteroleptic complexes with $\mathrm{SO}_{3}$-Ph-BTBP and TEDGA in aqueous solution was also investigated. Fig. 7 displays the normalised $\mathrm{Cm}(\mathrm{III})$ emission spectra of a titration experiment with an aqueous solution 


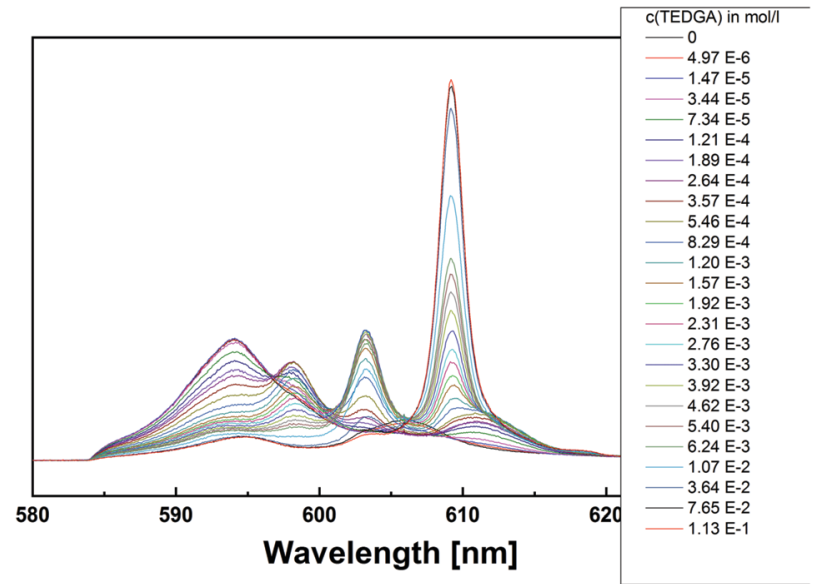

Fig. 7 Normalised emission spectra of $\mathrm{Cm}(\mathrm{III})$ in $10^{-3} \mathrm{~mol} \mathrm{~L}^{-1} \mathrm{HClO}_{4}$ solution at increasing TEDGA concentration in the presence of $4 \times 10^{-7} \mathrm{~mol} \mathrm{~L}^{-1}$ $\mathrm{SO}_{3}-\mathrm{Ph}-\mathrm{BTBP}$.

containing initially $4 \times 10^{-7} \mathrm{~mol} \mathrm{~L}^{-1}$ of $\mathrm{SO}_{3}$-Ph-BTBP and increasing TEDGA concentration.

The initial $\mathrm{Cm}$ (III) emission spectrum (in the absence of TEDGA) displays three emission bands at $593.9 \mathrm{~nm}, 606.2 \mathrm{~nm}$ and $618.9 \mathrm{~nm}$, corresponding to the $\mathrm{Cm}(\mathrm{III})$ aqua ion and $1: 1$ and $1: 2$ complexes, ${ }^{17}\left[\mathrm{Cm}\left(\mathrm{SO}_{3}-\mathrm{Ph}-\mathrm{BTBP}\right)\right]^{-}$and $\left[\mathrm{Cm}\left(\mathrm{SO}_{3}-\mathrm{Ph}-\right.\right.$ BTBP $\left.)_{2}\right]^{5-}$. Upon addition of TEDGA, four additional spectra are observed. Three of them (displaying peak maxima at $598.3 \mathrm{~nm}$, $603.3 \mathrm{~nm}$ and $609.2 \mathrm{~nm})$ are assigned to the $\left.[\text { Cm(TEDGA })_{n}\right]^{3+}$ ( $n=1-3$ ) complexes. ${ }^{36}$ Finally, a peak with a maximum at $612 \mathrm{~nm}$ is observed. Following the reasoning explained for the TEDGA/ $\mathrm{SO}_{3}-\mathrm{Ph}-\mathrm{BTP}$ heteroleptic complexes, this emission band is assigned to the heteroleptic complex, $\left[\mathrm{Cm}\left(\mathrm{SO}_{3}-\mathrm{Ph}\right.\right.$ BTBP)(TEDGA)] $]^{-}$.

Pure component spectra obtained by peak deconvolution are given in Fig. 8 .

The double logarithmic plot of the molar concentration ratio of $c\left[\mathrm{Cm}\left(\mathrm{SO}_{3}-\mathrm{Ph}-\mathrm{BTBP}\right)(\mathrm{TEDGA})^{-}\right]$to $c\left[\mathrm{Cm}\left(\mathrm{SO}_{3}-\mathrm{Ph}-\mathrm{BTBP}\right)^{-}\right]$

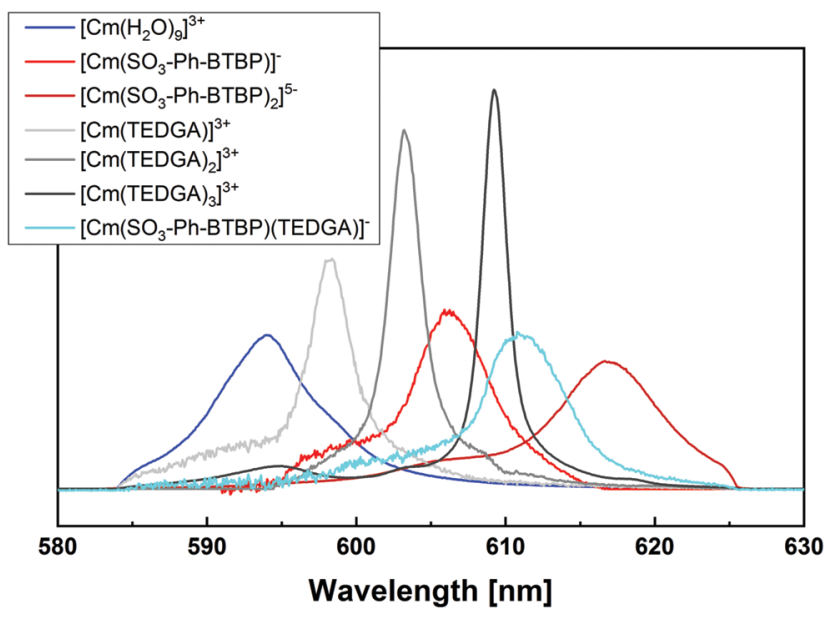

Fig. 8 Pure component spectra of the $\mathrm{Cm}$ (III) complexes with $\mathrm{SO}_{3}-\mathrm{Ph}$ BTBP, and TEDGA and heteroleptic complexes.

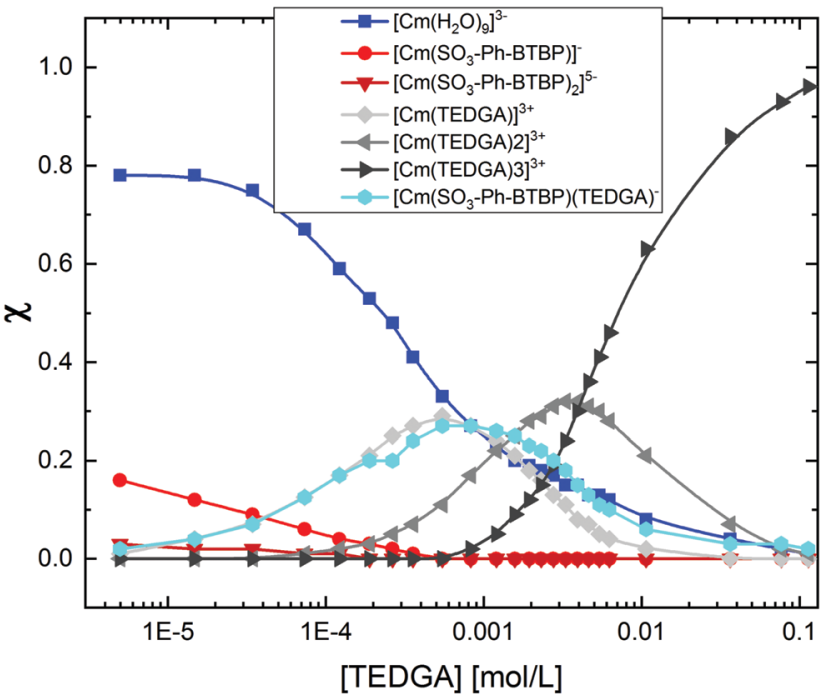

Fig. $9 \mathrm{Cm}$ (III) species distribution in $10^{-3} \mathrm{~mol} \mathrm{~L}^{-1} \mathrm{HClO}_{4}$ as a function of the TEDGA concentration in the presence of $4 \times 10^{-7} \mathrm{~mol} \mathrm{~L}^{-1} \mathrm{SO}_{3}-\mathrm{Ph}-\mathrm{BTBP}$.

yielded a value of 1.1 for the addition of TEDGA to the $\mathrm{Cm}\left(\mathrm{SO}_{3}\right.$ Ph-BTBP $)^{-}$complex, evidencing the formation of the heteroleptic complex, [Cm(SO $\mathrm{SO}_{3}$-Ph-BTBP)(TEDGA $\left.)\right]^{-}$.

Applying the pure component spectra (Fig. 8), the fractions of the complex species were determined as a function of the TEDGA concentration. The distribution of the Cm(III) species as a function of the TEDGA concentration in the presence of $\mathrm{SO}_{3}$ Ph-BTBP is shown in Fig. 9. Under the experimental conditions $\left(10^{-3} \mathrm{~mol} \mathrm{~L}^{-1} \mathrm{HClO}_{4}, 4 \times 10^{-7} \mathrm{~mol} \mathrm{~L}^{-1} \mathrm{SO}_{3}\right.$-Ph-BTBP$)$, the heteroleptic complex, $\left[\mathrm{Cm}\left(\mathrm{SO}_{3} \text {-Ph-BTBP)(TEDGA }\right)\right]^{-}$is present over a wide range of TEDGA concentrations, $\left(10^{-5}-10^{-1}\right) \mathrm{mol} \mathrm{L}^{-1}$. It has a maximum fraction of approximately $25 \%$ at $8 \times 10^{-4} \mathrm{~mol} \mathrm{~L}^{-1}$ TEDGA.

The fluorescence lifetime of $\mathrm{Cm}\left(\mathrm{SO}_{3}\right.$-Ph-BTBP)(TEDGA ${ }^{-}$was not determined because the relative intensity of its emission band was too low and it overlapped with other emission bands.

\section{Structural information}

Supporting the findings from the experiments, all optimised heteroleptic complexes were found to be true minima on the potential surface. The bond distances are similar to those in the corresponding lipophilic BT(B)P derivatives, ${ }^{41}$ except for those with the pyridine nitrogen atom, $\mathrm{N}_{\text {pyr. }}$. The repulsion of the negatively charged sulfonate groups leads to an increased flexion of the ligand, increasing the $\mathrm{Cm}-\mathrm{N}_{\text {pyr }}$ bond length (Table 1).

In particular, the bonds with the $\mathrm{N}_{\text {pyr }}$ and $\mathrm{N}_{\text {tri }}$ atoms in the $\left[\mathrm{Cm}\left(\mathrm{SO}_{3}-\mathrm{Ph}-\mathrm{BTBP}\right)(\mathrm{TEDGA})_{2}\right]^{-}$complex are elongated to

Table 1 Calculated metal ion-ligand bond distances (in $\AA$ ) for the heteroleptic $\mathrm{SO}_{3}-\mathrm{Ph}-\mathrm{BTP}^{4-} /$ TEDGA complexes

\begin{tabular}{lllll}
\hline & $\begin{array}{l}\mathrm{Cm}- \\
\mathrm{N}_{\text {pyr }}\end{array}$ & $\begin{array}{l}\mathrm{Cm}- \\
\mathrm{N}_{\text {tri }}\end{array}$ & $\begin{array}{l}\mathrm{Cm}^{-} \\
\mathrm{O}_{\text {eth }}\end{array}$ & $\begin{array}{l}\mathrm{Cm}- \\
\mathrm{O}_{\text {amid }}\end{array}$ \\
\hline$\left[\mathrm{Cm}\left(\mathrm{SO}_{3}-\mathrm{Ph}-\mathrm{BTP}\right)\left(\mathrm{H}_{2} \mathrm{O}\right)_{6}\right]^{-}$ & 2.85 & 2.63 & - & - \\
{$\left[\mathrm{Cm}\left(\mathrm{SO}_{3}-\mathrm{Ph}-\mathrm{BTP}\right)(\mathrm{TEDGA})\left(\mathrm{H}_{2} \mathrm{O}\right)_{3}\right]^{-}$} & 2.73 & 2.58 & 2.53 & 2.39 \\
{$\left[\mathrm{Cm}\left(\mathrm{SO}_{3}-\mathrm{Ph}-\mathrm{BTP}\right)(\mathrm{TEDGA})_{2}\right]^{-}$} & 2.69 & 2.61 & 2.59 & 2.43
\end{tabular}


Table 2 Calculated metal ion-ligand bond distances (in $\AA$ ) for the heteroleptic $\mathrm{SO}_{3}-\mathrm{Ph}-\mathrm{BTBP}^{4-} /$ TEDGA complexes

\begin{tabular}{lllll}
\hline & $\mathrm{Cm}^{-}$ & $\mathrm{Cm}-$ & $\mathrm{Cm}-$ & $\mathrm{Cm}-$ \\
& $\mathrm{N}_{\text {pyr }}$ & $\mathrm{N}_{\text {tri }}$ & $\mathrm{O}_{\text {eth }}$ & $\mathrm{O}_{\text {amid }}$ \\
\hline$\left[\mathrm{Cm}\left(\mathrm{SO}_{3}-\mathrm{Ph}-\mathrm{BTBP}\right)\left(\mathrm{H}_{2} \mathrm{O}\right)_{5}\right]^{-}$ & 2.76 & 2.55 & - & - \\
{$\left[\mathrm{Cm}\left(\mathrm{SO}_{3}-\mathrm{Ph}-\mathrm{BTBP}\right)(\mathrm{TEDGA})\left(\mathrm{H}_{2} \mathrm{O}\right)_{2}\right]^{-}$} & 2.71 & 2.53 & 2.56 & 2.44 \\
{$\left[\mathrm{Cm}\left(\mathrm{SO}_{3}-\mathrm{Ph}-\mathrm{BTBP}\right)(\mathrm{TEDGA})_{2}\right]^{-}$} & 3.01 & 2.78 & 2.60 & 2.46
\end{tabular}

compensate for the increased coordination number of the $\mathrm{Cm}$ (III) ion. However, this change in the coordination mode is unlikely to prevail in solution due to the large $\mathrm{Cm}-\mathrm{N}_{\mathrm{pyr}}$ bond length. This is in agreement with the results of TRLFS where the $\left[\mathrm{Cm}\left(\mathrm{SO}_{3}-\mathrm{Ph}-\mathrm{BTBP}\right)(\mathrm{TEDGA})_{2}\right]^{-}$complex was not observed (Table 2).

\section{Conclusions}

Solvent extraction systems combining a non-selective extracting agent, TODGA, and a water soluble complexing agent, $\mathrm{SO}_{3}-\mathrm{Ph}-$ BTP, $\mathrm{SO}_{3}$-Ph-BTBP, or $\mathrm{SO}_{3}$-Ph-BTPhen, have been developed and tested to separate An(III) from Ln(III). Results from solvent extraction experiments cannot be explained by simple models assuming the formation of only TODGA complexes in the organic phase and $\mathrm{SO}_{3}-\mathrm{Ph}-\mathrm{BTP} / \mathrm{SO}_{3}-\mathrm{Ph}-\mathrm{BTBP} / \mathrm{SO}_{3}-\mathrm{Ph}-\mathrm{BTPhen}$ complexes in the aqueous phase. A spectroscopic investigation was performed to understand whether the formation of heteroleptic complexes in the organic phase explains this discrepancy.

The speciation in organic and aqueous phase samples from $\mathrm{Cm}$ (III) extraction experiments with TODGA and $\mathrm{SO}_{3}-\mathrm{Ph}-\mathrm{BTP}$ or $\mathrm{SO}_{3}$-Ph-BTBP was investigated by TRLFS. Only homoleptic complexes, $\left[\mathrm{Cm}(\mathrm{TODGA})_{3}\right]\left(\mathrm{NO}_{3}\right)_{3}$ and $\left[\mathrm{Cm}\left(\mathrm{SO}_{3}-\mathrm{Ph}-\mathrm{BTP}\right)_{3}\right]^{9-}$ or $\left[\mathrm{Cm}\left(\mathrm{SO}_{3}-\mathrm{Ph}-\mathrm{BTBP}\right)_{2}\right]^{5-}$, were detected in the organic and aqueous phases, respectively.

However, the presence of low concentrations of $\mathrm{SO}_{3}-\mathrm{Ph}-\mathrm{BTP}$ in the organic phase by an extraction experiment employing a rather large concentration of $\mathrm{Eu}(\mathrm{III})$ was detected photometrically. Since in the absence of $\mathrm{Eu}(\mathrm{III})$, no $\mathrm{SO}_{3}-\mathrm{Ph}-\mathrm{BTP}$ was detected in the organic phase, this result is indirect evidence for the formation of a heteroleptic complex. Its concentration was estimated to be as low as $0.2 \%$ relative to that of the $\left[\mathrm{Eu}(\mathrm{TODGA})_{3}\right]\left(\mathrm{NO}_{3}\right)_{3}$ complex, which explains why it went undetected by TRLFS.

Finally, aqueous monophasic systems containing TEDGA and $\mathrm{SO}_{3}-\mathrm{Ph}-\mathrm{BTP}$ or $\mathrm{SO}_{3}-\mathrm{Ph}-\mathrm{BTBP}$ were studied. With $\mathrm{SO}_{3}-\mathrm{Ph}-\mathrm{BTP}$, two heteroleptic complexes, $\left[\mathrm{Cm}\left(\mathrm{SO}_{3}-\mathrm{Ph}-\mathrm{BTP}\right)(\mathrm{TEDGA})\right]^{-}$and $\left[\mathrm{Cm}\left(\mathrm{SO}_{3}-\right.\right.$ Ph-BTP)(TEDGA $\left.)_{2}\right]^{-}$, were identified. The heteroleptic complex $\left[\mathrm{Cm}\left(\mathrm{SO}_{3} \text {-Ph-BTBP)(TEDGA }\right)\right]^{-}$was identified in the system containing $\mathrm{SO}_{3}$-Ph-BTBP. Optimised structures of these complexes were calculated by DFT.

While this study is the first to support the existence of heteroleptic complexes in solvent extraction systems combining heterocyclic N-donor ligands and TODGA, its results may be of more general relevance: for example, in the case of another water-soluble $\mathrm{N}$-donor ligand, 2,6-bis(1H-1,2,3-triazol-4-yl) pyridine, similar discrepancies between the results of solvent extraction ${ }^{47}$ and spectroscopic studies ${ }^{48}$ were observed.

\section{Conflicts of interest}

There are no conflicts to declare.

\section{Acknowledgements}

Financial support for this research was provided by the European Commission via the following projects: SACSESS (contract No. FP7-Fission-2012-323282), GENIORS (Horizon 2020 grant agreement No. 755171) and TALISMAN (contract No. FP7-Fission-2012-323300).

\section{Notes and references}

1 C. Poinssot, S. Bourg, N. Ouvrier, N. Combernoux, C. Rostaing, M. Vargas-Gonzalez and J. Bruno, Energy, 2014, 69, 199.

2 C. Poinssot, S. Bourg and B. Boullis, Prog. Nucl. Energy, 2016, 92, 234.

3 C. Poinssot, S. Bourg, S. Grandjean and B. Boullis, Procedia Chem., 2016, 21, 536.

4 OECD-NEA, Advanced Nuclear Fuel Cycles and Radioactive Waste Management, NEA No. 5990, OECD, Nuclear Energy Agency (NEA), Paris, 2006.

5 OECD-NEA, Potential Benefits and Impacts of Advanced Nuclear Fuel Cycles with Actinide Partitioning and Transmutation, NEA No. 6894, OECD, Nuclear Energy Agency (NEA), Paris, 2011.

6 C. Poinssot, C. Rostaing, S. Greandjean and B. Boullis, Procedia Chem., 2012, 7, 349.

7 W. B. Lanham and T. C. Runion, PUREX process for plutonium and uranium recovery, USAEC report ORNL-479, Oak Ridge National Laboratory, USA, 1949.

8 B. Dinh, P. Moisy, P. Baron, J.-N. Calor, D. Espinoux, B. Lorrain and M. Benchikouhne-Ranchoux, Proc. Internat. Solvent Extr. Conf. (ISEC 2008), Tucson, Arizona, USA, 15-19 September, 2008.

9 R. J. Taylor, C. R. Gregson, M. J. Carrott, C. Mason and M. J. Sarsfield, Solvent Extr. Ion Exch., 2013, 31, 442.

10 G. T. Seaborg, Radiochim. Acta, 1993, 61, 115.

11 C. Ekberg, A. Fermvik, T. Retegan, G. Skarnemark, M. R. S. Foreman, M. J. Hudson, S. Englund and M. Nilsson, Radiochim. Acta, 2008, 96, 225.

12 F. W. Lewis, M. J. Hudson and L. M. Harwood, Synlett, 2011, 2609.

13 P. J. Panak and A. Geist, Chem. Rev., 2013, 113, 1199-1236.

14 A. Geist, U. Müllich, D. Magnusson, P. Kaden, G. Modolo, A. Wilden and T. Zevaco, Solvent Extr. Ion Exch., 2012, 30, 433.

15 C. M. Ruff, U. Müllich, A. Geist and P. J. Panak, Dalton Trans., 2012, 41, 14594. 
16 H. Galán, D. Munzel, A. Núñez, U. Müllich, J. Cobos and A. Geist, Proc. Internat. Solvent Extr. Conf. (ISEC 2014), Würzburg, Germany, 7-11 September, 2014.

17 C. Wagner, U. Müllich, A. Geist and P. J. Panak, Dalton Trans., 2015, 44, 17143.

18 C. Wagner, U. Müllich, A. Geist and P. J. Panak, Solvent Extr. Ion Exch., 2016, 34, 103.

19 F. W. Lewis, L. M. Harwood, M. J. Hudson, A. Geist, V. N. Kozhevnikov, P. Distler and J. John, Chem. Sci., 2015, 6, 4812 .

20 P. Kaufholz, F. Sadowski, A. Wilden, G. Modolo, F. W. Lewis, A. W. Smith and L. M. Harwood, Nukleonika, 2015, 60, 815.

21 P. Kaufholz, G. Modolo, A. Wilden, F. Sadowski, D. Bosbach, C. Wagner, A. Geist, P. J. Panak, F. W. Lewis and L. M. Harwood, Solvent Extr. Ion Exch., 2016, 34, 126.

22 A. Wilden, G. Modolo, P. Kaufholz, F. Sadowski, S. Lange, M. Sypula, D. Magnusson, U. Müllich, A. Geist and D. Bosbach, Solvent Extr. Ion Exch., 2015, 33, 91.

23 M. Carrott, K. Bell, J. Brown, A. Geist, C. Gregson, X. Hérès, C. Maher, R. Malmbeck, C. Mason, G. Modolo, U. Müllich, M. Sarsfield, A. Wilden and R. Taylor, Solvent Extr. Ion Exch., 2014, 32, 447.

24 M. Carrott, A. Geist, X. Hérès, S. Lange, R. Malmbeck, M. Miguirditchian, G. Modolo, A. Wilden and R. Taylor, Hydrometallurgy, 2015, 152, 139.

25 M. Carrott, C. Maher, C. Mason, M. Sarsfield and R. Taylor, Sep. Sci. Technol., 2016, 51, 2198.

26 R. Malmbeck, D. Magnusson, S. Bourg, M. Carrott, A. Geist, X. Hérès, M. Miguirditchian, G. Modolo, U. Müllich, C. Sorel, R. Taylor and A. Wilden, Radiochim. Acta, 2019, submitted.

27 P. Lindqvist-Reis, R. Klenze, G. Schubert and T. Fanghänel, J. Phys. Chem. B, 2005, 109, 3077.

28 P. Lindqvist-Reis, C. Walther, R. Klenze and N. M. Edelstein, J. Phys. Chem. C, 2009, 113, 449.

29 M. A. Denecke, A. Rossberg, P. J. Panak, M. Weigl, B. Schimmelpfennig and A. Geist, Inorg. Chem., 2005, 44, 8418.

30 M. A. Denecke, P. J. Panak, F. Burdet, M. Weigl, A. Geist, R. Klenze, M. Mazzanti and K. Gompper, C. R. Chim, 2007, 10, 872 .
31 N. L. Banik, B. Schimmelpfennig, C. M. Marquardt, B. Brendebach, A. Geist and M. A. Denecke, Dalton Trans., 2010, 39, 5117.

32 N. L. Banik, M. A. Denecke, A. Geist, G. Modolo, P. J. Panak and J. Rothe, Inorg. Chem. Commun., 2013, 29, 172.

33 C. M. Ruff, Spektroskopische und thermodynamische Untersuchung der Komplexierung von Cm(III) und Eu(III) mit hydrophilen Bis-Triazinylpyridinen, Dissertation, Universität Heidelberg, Germany, 2013.

34 Ł. Steczek, M. Rejnis, J. Narbutt, M.-C. Charbonnel and P. Moisy, J. Radioanal. Nucl. Chem., 2016, 309, 891.

35 S. Chapron, C. Marie, V. Pacary, M. T. Duchesne, G. Arrachart, S. Pellet-Rostaing and M. Miguirditchian, Procedia Chem., 2016, 21, 133.

36 L. Klaß, A. Wilden, F. Sadowski, C. Wagner, A. Geist, P. J. Panak, I. Herdzik-Koniecko, J. Narbutt and G. Modolo, Solvent Extr. Ion Exch., 2018, submitted.

37 G. L. Traister and A. A. Schilt, Anal. Chem., 1976, 48, 1216. 38 Y. Sasaki and G. R. Choppin, Anal. Sci., 1996, 12, 225.

39 A. D. Becke, J. Chem. Phys., 1993, 98, 1372.

40 Turbomole, http://www.turbomole.com.

41 M. Trumm and B. Schimmelpfennig, Mol. Phys., 2016, 114, 876.

42 W. Küchle, M. Dolg, H. Stoll and H. Preuss, J. Chem. Phys., 1994, 100, 7535.

43 A. Schäfer, C. Huber and R. Ahlrichs, J. Chem. Phys., 1994, 100, 5829.

44 A. Wilden, G. Modolo, S. Lange, F. Sadowski, B. B. Beele, A. Skerencak-Frech, P. J. Panak, M. Iqbal, W. Verboom, A. Geist and D. Bosbach, Solvent Extr. Ion Exch., 2014, 32, 119.

45 S. Trumm, G. Lieser, M. R. S. Foreman, P. J. Panak, A. Geist and T. Fanghänel, Dalton Trans., 2010, 39, 923.

46 M. Trumm, C. Wagner, B. Schimmelpfennig, A. Geist and P. J. Panak, Dalton Trans., 2016, 45, 12308.

47 E. Macerata, E. Mossini, S. Scaravaggi, M. Mariani, A. Mele, W. Panzeri, N. Boubals, L. Berthon, M.-C. Charbonnel, F. Sansone, A. Arduini and A. Casnati, J. Am. Chem. Soc., 2016, 138, 7232.

48 C. Wagner, E. Mossini, E. Macerata, M. Mariani, A. Arduini, A. Casnati, A. Geist and P. J. Panak, Inorg. Chem., 2017, 56, 2135. 